Dunamis: Jurnal Teologi dan Pendidikan Kristiani

Volume 6, Nomor 1 (Oktober 2021)

ISSN 2541-3937 (print), 2541-3945 (online)

https://www.sttintheos.ac.id/e-journal/index.php/dunamis

DOI: $10.30648 /$ dun.v6i1.640

Submitted: 13 Agustus 2021

Accepted: 2 September 2021

Published: 31 Oktober 2021

\title{
Aktualisasi Amanat Agung di Era Masyarakat 5.0
}

\section{Paulus Purwoto $^{1 *}$; Asih Rachmani Endang Sumiwi²; Alfons Renaldo Tampenawas ${ }^{3}$; Joseph Christ Santo ${ }^{4}$ \\ Sekolah Tinggi Teologi Torsina ${ }^{1 ; 2 ; 4}$; Sekolah Tinggi Teologi Yerusalem Baru ${ }^{3}$ pauluspurwoto022@gmail.com*}

\begin{abstract}
Society 5.0 is the concept of a new life order that focuses on humans and based on digital technology to support human work. Meanwhile, the Church has the task to carry out the Great Commission of Christ according to Matthew 28:18-20. The problem is how to implement the Great Commission of Christ in this 5.0 society era. The method used in this study is grammatical and lexical study of Matthew 28:18-20. Through this study, it could be concluded that the actualization of the Great Commission of Christ requires new innovations, from previously onsite-based missions to digital missions. Missionaries are required to have capability in mission activities innovation through digital technology.
\end{abstract}

Keywords: society 5.0 era; Great Commission; Matthew 28:18-20; mission; digital technology

\begin{abstract}
Abstrak
Masyarakat 5.0 adalah konsep tatanan kehidupan baru yang berfokus pada manusia dan berbasiskan teknologi digital untuk mendukung pekerjaan manusia. Sedangkan Gereja memiliki tugas untuk melaksanakan Amanat Agung Kristus berdasarkan Matius 28:18-20. Problemnya adalah bagaimanakah implementasi Amanat Agung Kristus di era masyarakat 5.0 ini. Metode yang digunakan dalam kaijian ini adalah studi gramatikal dan leksikal Matius 28:18-20. Melalui kajian ini dapat disimpulkan bahwa aktualisasi Amanat Agung Kristus menuntut inovasi baru, dari sebelumnya misi berbasis on site menuju digital mision. Misionaris dituntut untuk memiliki kemampuan berinovasi dalam aktivitas misi melalui teknologi digital.
\end{abstract}

Kata Kunci: era masyarakat 5.0; Amanat Agung; Matius 28:18-20; misi; teknologi digital 


\section{PENDAHULUAN}

Amanat Agung Kristus merupakan hati Allah yang terlisankan dari mulut Allah sendiri pasca kejatuhan manusia dalam dosa seperti terdokumentasi dalam Kejadian 3:15 yang dikenal dengan protoevangelion yang oleh George W. Peters disebut bagaikan bintang fajar di tengah malam yang paling gelap bagi umat manusia. ${ }^{1}$ Selanjutnya Peters menulis bahwa berdasarkan Kejadian 3:15 tersebut terdapat enam fakta tentang keselamatan, di antaranya: originator keselamatan adalah Allah, keselamatan akan menghancurkan kuasa iblis, keselamatan mempengaruhi seluruh umat manusia, keselamatan akan datang melalui seorang Perantara yang secara organis berhubungan dengan manusia, keselamatan terkait dengan penderitaan Sang Penebus dan keselamatan akan terjadi dalam sejarah. ${ }^{2}$ Hal tersebut merupakan nubuatan Mesianik yang merupakan penginjilan pertama yang memiliki tujuan universal serta menjadi tema utama di seluruh Perjanjian Lama yang berakhir dengan puncak peristiwa inkarnasikematian-kebangkitan Kristus. Peristiwa ini

1 George W. Peters, Teologi Alkitabiah tentang Pekabaran Injil, Cetakan Ke. (Malang: Penerbit Gandum Mas Malang, 2020), 101.

${ }^{2}$ Peters, Teologi Alkitabiah tentang Pekabaran Injil. 3 Paulus Purwoto, "Makna Proselitisasi Di Masa Intertestamental Bagi Misi," EPIGRAPHE: Jurnal Teologi dan Pelayanan Kristiani 4, no. 2 (2020).

${ }^{4}$ Harianto GP, Teologi Misi dari Misio Dei Menuju Misio Ecclesia, Cetakan ke. (Yogyakarta: Penerbit ANDI, 2017), 221. merupakan kabar baik atau euanggelion yang dinanti-nanti manusia sepanjang zaman. Upaya pewartaan kabar baik tersebut terus dilaksanakan oleh para nabi di berbagai era Perjanjian Lama, juga ketika masa Intertestamental dengan melakukan proselitisasi bagi bangsa-bangsa non-Yahudi. ${ }^{3}$

Selanjutnya dalam masa Perjanjian Baru, tugas dan tanggung jawab bagi tugas pewartaan kabar baik tersebut, diberikan kepada gereja yang lazim disebut sebagai mandat Amanat Agung Kristus, yang terdokumentasi dalam keempat Kitab Injil khususnya Matius 28:18-20. ${ }^{4}$ Sproul menulis bahwa satu tanda gereja yang sejati adalah gereja tersebut melaksanakan misi dengan baik. ${ }^{5}$ Senada dengan Sproul, Purwoto dalam penelitian terdahulu juga menulis bahwa salah satu tanda gereja kontemporer yang sejati adalah apabila gereja tersebut misioner. ${ }^{6}$ Susanto menulis bahwa gereja sejati adalah gereja yang berfokus pada gerakan misioner dengan pendekatan misi kontekstual. ${ }^{7}$ Dari berbagai pendapat dari para penulis di atas, nyata bahwa misi merupakan denyut nadi Allah sepanjang segala

\footnotetext{
${ }^{5}$ R.C. Sproul, Kebenaran-kebenaran Dasar Iman Kristen, Cetakan Ke. (Malang: Departemen Literatur SAAT, 2002), 665.

6 Paulus Purwoto, "Tinjauan Teologis Tentang Gereja Sejati dan Aplikasinya Bagi Pelayanan Gereja Kontemporer," Shamayim : Jurnal Teologi dan Pendidikan Kristiani 1, no. 1 (2020): 45-57.

7 Hery Susanto, "Gereja Yang Berfokus Pada Gerakan Misioner," FIDEI: Jurnal Teologi Sistematika dan Praktika 2, no. 1 (2019): 62-80.
} 
zaman, yang harus juga menjadi denyut nadi pelayanan gereja sepanjang segala abad khususnya di era masyarakat 5.0 ini.

Dalam aktualisasi Amanat Agung Kristus tersebut diperlukan optimalisasi segenap daya dan upaya sehingga mandat tersebut dapat dilaksanakan dengan baik sesuai kehendak Tuhan. Paulus Purwoto dan Asih Rachmani menulis bahwa manajemen merupakan salah satu hal yang fundamental dan penting untuk dimiliki oleh orang percaya demi berhasilnya pelaksanaan Amanat Agung Kristus. ${ }^{8}$ Manajemen penginjilan merupakan salah satu alat penunjang bagi efisiensi pelaksanaan Amanat Agung Kristus, karena dalam tataran praktis pelaksanaan Amanat Agung Kristus selalu menghadapi tantangan yang berbeda di setiap era. Olehnya diperlukan rekonstruksi pelaksanaan Amanat Agung sesuai dengan tantangan yang dihadapi di masing-masing eranya. Demikian juga di era digital ${ }^{9}$, era yang disebut era 4.0, gereja perlu mengoptimalkan semua karunia jemaat bagi pelaksanaan tugas Amanat Agung tersebut. ${ }^{10}$ Dunia kini tengah menjalani era 4.0 dengan berbagai

\footnotetext{
8 Paulus Purwoto dan Asih Rachmani Endang Sumiwi, "Pola Manajemen Penginjilan Paulus Menurut Kitab Kisah Para Rasul 9-28," Angelion: Jurnal Teologi dan Pendidikan Kristen Vol 1, No, no. 2 (2020): 113-131.

9 Handreas Hartono, "Mengaktualisasikan Amanat Agung Matius 28: 19-20 dalam Konteks Era Digital," KURIOS (Jurnal Teologi dan Pendidikan Agama Kristen) 4, no. 2 (2018): 19-20.

${ }^{10}$ Eben Munthe, "Mengoptimalkan Karunia dalam Jemaat untuk Melakukan Misi Amanat Agung di Era
}

kompleksitas perubahannya, dan sedang menuju ke era masyarakat 5.0, yang merupakan tatanan kehidupan yang baru yang berfokus pada manusia dan berbasis big data dan robot yang bertujuan untuk melakukan atau mendukung pekerjaan manusia. ${ }^{11}$ Pelaksanaan Amanat Agung di era masyarakat $5.0 \mathrm{ini}$, tentu memerlukan penanganan dengan semangat kerja keras, kerja cerdas, kerja tuntas serta kerja ikhlas.

Penelitian tentang topik ini telah dilakukan oleh peneliti-peneliti sebelumnya seperti yang dilakukan oleh Handreas Hartono yang membahas tentang mengaktualisasikan Amanat Agung Matius 28:1920 dalam konteks era digital. ${ }^{12}$ Dalam penelitian tersebut Hartono berfokus pada perlunya gereja mengaplikasikan kemajuan teknologi bagi pelaksanaan tugas Amanat Agung Kristus. Peneliti yang lain yang membahas topik ini adalah Eben Munthe dengan memfokuskan penelitiannya pada mengoptimalkan karunia dalam jemaat untuk melaksanakan misi Amanat Agung di era 4.0. ${ }^{13}$ Beberapa penelitian tersebut relevan dengan penelitian ini, yaitu memiliki

4.0," EPIGRAPHE: Jurnal Teologi dan Pelayanan Kristiani 3, no. 2 (2019): 133.

11 Faulinda Ely Nastiti dan Aghni Rizqi Ni'mal 'Abdu, "Kesiapan Pendidikan Indonesia Menghadapi era society 5.0," Edcomtech 5, no. 1 (2020): 61-66.

12 Hartono, "Mengaktualisasikan Amanat Agung Matius 28 : 19-20 dalam Konteks Era Digital."

${ }^{13}$ Munthe, "Mengoptimalkan Karunia dalam Jemaat untuk Melakukan Misi Amanat Agung di Era 4.0." 
kesamaan obyek penelitian tentang pelaksanaan Amanat Agung di era digital, namun juga memiliki perbedaan. Kebaruan dalam penelitian ini terdapat pada fokus penelitian, sebagaimana konsep Society 5.0 adalah memanusiakan manusia melalui teknologi, peneliti membahas implementasi Amanat Agung berdasarkan Matius 28:18-20 konteks manusia yang hidup di era Society 5.0. Bertitik tolak dari hal tersebut di atas maka penelitian ini bertujuan memaparkan konsep Amanat Agung berdasarkan Matius 28:18-20 dan penerapannya di era Society 5.0.

\section{METODE PENELITIAN}

Penelitian ini menggunakan metode kualitatif $^{14}$ dengan pendekatan penelitian kepustakaan dan hermeneutika. Analisis leksikal dan gramatikal dilakukan atas teks Matius 28:18-20, khususnya terhadap katakata kerja yang berhubungan dengan Amanat Agung, sehingga ditemukan aspekaspek Amanat Agung dan keterkaitan masing-masing aspek satu sama lain. Pembahasan diperkuat dengan sumber-sumber literatur yang membahas Matius 28:18-20, buku teks, dan berbagai artikel jurnal yang berkorelasi dengan masalah penelitian. Pen-

14 Lexy J. Moleong, Metodologi Penelitian Kualitatif, Cet. Ke-36. (Bandung: PT Remaja Rosdakarya, 2017), 6.

${ }^{15}$ GP, Teologi Misi dari Misio Dei Menuju Misio Ecclesia. dekatan tematis digunakan untuk mendeskripsikan aktualisasi amanat Agung Kristus berdasarkan Matius 28:18-20 di era masyarakat 5.0. Selanjutnya peneliti menganalisis sumber-sumber yang terkait dengan menggunakan analisis dokumen/analisis isi yang merupakan kajian yang menitikberatkan interpretasi bahan tertulis berdasarkan konteksnya untuk mendapatkan jawaban atas masalah penelitian.

\section{HASIL DAN PEMBAHASAN}

\section{Konsep Amanat Agung Kristus Menurut Matius 28:18-20}

Amanat Agung terdokumentasi dalam keempat Injil, khususnya dalam Injil Matius 28:18-20. Menurut ayat tersebut gereja sepanjang segala abad memiliki tugas pergi ke seluruh bangsa, sebagai utusan untuk menjadi saksi bagi orang yang belum percaya. ${ }^{15}$ Penyelidikan tentang teks tersebut menurut David J. Bosch menarik minat dan terus berkembang di kalangan ahli Perjanjian Baru. ${ }^{16}$ Hal ini sekaligus membantah pendapat teolog pluralis yang beranggapan bahwa misi sebagai imperialisme dan kolonialisme Barat, bahkan dianggap sebagai keangkuhan, oleh sebab itu harus dihentikan karena tidak cocok dengan se-

\footnotetext{
${ }^{16}$ David J. Bosh, Transformasi Misi Kristen Sejarah Teologi Misi yang Mengubah dan Berubah, ed. Staf Redaksi BPK Gunung Mulia, Cetakan ke. (Jakarta: BPK Gunung Mulia, 2018), 88.
} 
mangat pluralisme agama, suku dan bangsa. ${ }^{17}$

Dalam Injil Matius ditunjukkan bahwa Kristus adalah penggenapan dari penglihatan-penglihatan dan nubuat-nubuat para nabi Perjanjian Lama, wujud dari harapanharapan serta cita-cita manusia, dan penggenapan dari semua kiasan Perjanjian Lama. ${ }^{18}$ Injil Matius menampilkan Kristus sebagai Raja yang telah menerima otoritas untuk melayani dan menyelamatkan manusia yang berdosa serta memberikan perintah untuk menjadikan semua bangsa menjadi murid-Nya. Tugas utama Amanat Agung Kristus dalam Injil Matius 28:18-20 adalah menjadikan murid (matheteusate), ini merupakan satu-satunya kata kerja imperatif dalam nas tersebut. Kata ini disertai dengan tiga kata kerja partisipel yang merupakan tiga aspek dari Amanat Agung, yaitu pergi (phoreuthentes), baptislah (baptizontes), dan ajarlah (didaskontes). Dengan demikian aktualisasi menjadikan murid dalam Amanat Agung Kristus menurut Injil Matius haruslah menyentuh ketiga aspek tugas utama tersebut yaitu pergi, membaptis, dan mengajar.

17 Marulak Pasaribu, Eksposisi Injil Sinoptik Mengenal Yesus yang Diberitakan dalam Injil Matius, Markus dan Lukas, ed. Tjuk Subandiah

\section{Hubungan antara Keempat Kata Kerja}

Empat kata kerja penting dalam Matius 28:19-20 adalah $\mu \alpha \theta \eta \tau \varepsilon v ́ \sigma \alpha \tau \varepsilon$

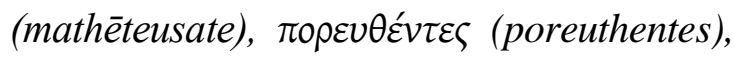
$\beta \alpha \pi \tau i \zeta \zeta o v \tau \varepsilon \varsigma$ (baptizontes), dan $\delta i \delta \alpha ́ \sigma \kappa o v \tau \varepsilon \varsigma$ (didaskontes). Empat kata kerja tersebut bisa dipandang sebagai unsur-unsur yang perlu dijabarkan. Kata $\mu \alpha \theta \eta \tau \varepsilon v ́ \sigma \alpha \tau \varepsilon$ (mathēteusate) memiliki modus yang berbeda dibandingkan tiga kata kerja lainnya. Kata ini memiliki modus imperatif, sedangkan tiga kata yang lain memiliki modus partisipel. Struktur ini mengandung makna, bahwa $\mu \alpha \theta \eta \tau \varepsilon v ́ \sigma \alpha \tau \varepsilon$ (mathēteusate) adalah perintah yang utama, sedangkan $\pi \circ \rho \varepsilon v \theta \varepsilon \dot{v} \tau \varepsilon \varsigma$ (poreuthentes), $\beta \alpha \pi \tau i \zeta \zeta o v \tau \varepsilon \varsigma$ (baptizontes), dan $\delta i \delta \alpha ́ \sigma \kappa o v \tau \varepsilon \varsigma$ (didaskontes) merupakan keterangan dari perintah $\mu \alpha \theta \eta \tau \varepsilon v ́ \sigma \alpha \tau \varepsilon$ (mathēteusate). Artinya, perintah utama adalah "menjadikan murid," dan dalam menjalankan perintah utama itu langkah-langkah yang menyertai adalah "pergi," "membaptis," dan "mengajar." Artinya setiap tindakan itu tidak berdiri sendiri. "Pergi" adalah bagian dari "menjadikan murid"; "membaptis" adalah bagian dari "menjadikan murid"; dan "mengajar" juga adalah bagian dari "menjadikan murid."

Kaihatu, Cetakan Ke. (Malang: Gandum Mas, 2019), 247.

18 Peters, Teologi Alkitabiah tentang Pekabaran Injil. 
Perintah Utama Amanat Agung: Jadikan Murid (mathēteusate)

Kata $\mu \alpha \theta \eta \tau \varepsilon v ́ \sigma \alpha \tau \varepsilon$ (mathēteusate) adalah kata kerja imperatif aoris aktif orang kedua jamak. Kata ini berasal dari kata da-

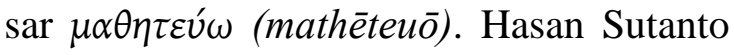
mengartikan kata ini sebagai "menjadi murid; menjadikan murid." 19 William Arndt dkk. mengartikan kata ini sebagai "(1) intransitif: be or become a pupil or disciple; (2) pasif: become a disciple; (3) transitif: make a disciple of, teach." ${ }^{20}$ Timothy Friberg dkk. mengartikan kata ini sebagai "(1) intransitif aktif: be or become a disciple of someone; intransitif pasif: become a disciple, be a follower; (2) transitif: make a disciple of someone, instruct, cause someone to become a follower." 21

Menurut Kittel, kata $\mu \alpha \theta \eta \tau \varepsilon v ́ \omega$ (mathēteuō) berakar dari kata $\mu \alpha \nu \theta \alpha ́ v \omega$ (manthánō) yang memiliki pengertian dasar (1) "to accustom oneself to something," (2) “to experience," (3) "to learn to know," (4) "to understand," (5) "to learn under instruction," dan (6) "to receive direction from

19 Hasan Susanto, Perjanjian Baru Interlinear Yunani-Indonesia dan Konkordansi Perjanjian Baru (PBIK) Jilid I-II (Malang: Lembaga Alkitab Indonesia, 2014), II:497.

${ }^{20}$ William Arndt et al., A Greek-English Lexicon of the New Testament and Other Early Christian Literature: A Translation and Adaption of the Fourth Revised and Augmented Edition of Walter Bauer's Griechisch-Deutsches Worterbuch Zu Den Schrift En Des Neuen Testaments Und Der Ubr (Chicago: University of Chicago Press, n.d.). a deity by oracle." Secara konsisten, penggunaannya mengimplikasikan proses intelektual yang selalu memiliki efek eksternal dan melingkupi inisiatif intelektual sadar dan tak sadar. Kata $\mu \alpha \theta \eta \tau \varepsilon v ́ \omega$ (mathēteuō) dalam penggunaan intransitif memiliki makna "to be or become the pupil." Matius 27:57 mengatakan dengan mengacu Yusuf dari Arimatea; dia dikatakan menjadi murid Yesus. Dalam penggunaan transitif khas (Mat. 13:52; 28:19; Kis. 14:21) PB juga menggunakan istilah "to make disciple." Mungkin di balik itu ada keyakinan PB bahwa panggilan adalah dasar dari pemuridan Yesus. ${ }^{22}$ Moulton juga menempatkan kata ini di bawah $\mu \alpha \nu \theta \alpha ́ v \omega$ (manthánō), dengan arti intransitif "menjadi murid"; transitif “memuridkan"; pasif "dimuridkan, dipelajari". 23

Berdasarkan data-data di atas, maka dapat diambil kesimpulan bahwa kata

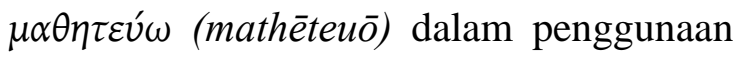
transitif aktif berarti "menjadikan murid," dalam penggunaan transitif pasif berarti “dijadikan murid," sedangkan dalam peng-

21 Timothy Friberg, Barbara Friberg, dan Neva F. Miller, Analytical Lexicon of the Greek New Testament, Baker's Greek New Testament library, vol. 4 (Grand Rapids, Mich.: Baker Books, 2000).

${ }^{22}$ Gerhard Kittel, Gerhard Friedrich, dan Geoffrey William Bromiley, Theological Dictionary of the New Testament, Translation of: Theologisches Worterbuch Zum Neuen Testament (Grand Rapids, Mich.: W.B. Eerdmans, n.d.).

${ }^{23}$ Harold K. Moulton, Leksikon Analitis Bahasa Yunani yang Direvisi (Jogjakarta: Randa Family Press, 2018). 
gunaan intransitif berarti "menjadi murid."

Sesuai ulasan yang diberikan oleh Kittel, maka Matius 28:19 menggunakan kata ini dalam makna transitif aktif. Hal ini diperjelas dengan adanya frasa dengan kasus akusatif yaitu $\pi \dot{\alpha} v \tau \alpha \quad \tau \dot{\alpha} \quad \check{\varepsilon} \theta v \eta$ (panta ta ethnē). Kata kerja yang diikuti dengan kasus akusatif menunjukkan bahwa kata kerja tersebut memiliki makna transitif aktif. Dengan demikian kata $\mu \alpha \theta \eta \tau \varepsilon v ́ \sigma \alpha \tau \varepsilon$ (mathēteusate) berarti perintah kepada orang kedua untuk menjadikan murid, atau dalam bahasa Indonesia sepadan dengan “jadikanlah murid." Objek dari kata kerja ini sudah jelas, yaitu $\pi \dot{\alpha} v \tau \alpha \tau \dot{\alpha} \varepsilon \varepsilon^{\prime} \theta v \eta$ (panta ta ethne) yang artinya segala bangsa atau segala etnis. Frasa ini memberikan pengertian bahwa jangkauan untuk menjadikan murid adalah segala bangsa, yakni semua manusia yang ada di muka bumi. Sehingga anak kalimat $\mu \alpha \theta \eta \tau \varepsilon v ́ \sigma \alpha \tau \varepsilon \pi \dot{\alpha} \nu \tau \alpha \tau \dot{\alpha} \tilde{\varepsilon}^{\prime} \theta \nu \eta$ (mathèteusate panta ta ethnē) dapat diartikan "Jadikanlah semua bangsa murid." Pemuridan merupakan tindakan yang perlu diimplementasikan kepada semua etnis yang ada di dunia ini. ${ }^{24}$ Sebagaimana struktur dalam bahasa Yunani, maka pemuridan dila-

24 I Putu Ayub Darmawan, "Jadikanlah Murid: Tugas Pemuridan Gereja Menurut Matius 28:1820," Evangelikal: Jurnal Teologi Injili dan Pembinaan Warga Jemaat (2019).

${ }^{25}$ Joseph Christ Santo, "Konsep Menjadikan Murid Berdasarkan Matius 28:19-20," Jurnal Teologi ElShadday 3, no. 2 (2016): 7-33. kukan dalam tiga aspek yaitu: pergi, membaptis dan mengajar. ${ }^{25}$

\section{Aspek Pertama Amanat Agung: Pergi ( $\pi \circ \rho \varepsilon v \theta \dot{\varepsilon} v \tau \varepsilon \varsigma)$}

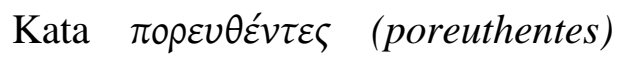
adalah kata kerja partisipel aoris pasif deponen nominatif maskulin orang kedua jamak. Menurut Hasan Sutanto kata ini bera-

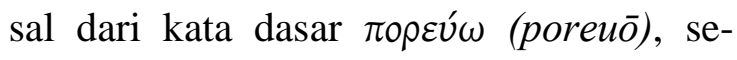
dangkan beberapa sumber lain mengatakan

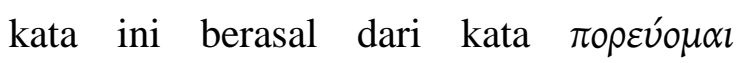
(poreuomai). Hasan Sutanto mengartikan kata ini sebagai "pergi; berangkat; bepergian; berjalan; meneruskan perjalanan; berlalu; hidup; meninggal." ${ }^{26}$ Dalam diatesis aktif, Liddel mengartikan kata ini dengan "to make to go, carry, convey; to bring, furnish, bestow, find," dan dalam diatesis pasif dan medial diartikan dengan "to be driven or carried; to go, walk, march; to go across, pass; to enter; to go over traverse; to walk." 27 Arndt dan Gingrich mengartikan kata ini dengan "go; proceed; travel"; dalam arti literal kata ini mengindikasikan suatu tempat asal, atau tempat yang dituju, dan bisa juga perjalanan menuju ke seberang. Tetapi dalam arti eufemisme kata ini

26 Hasan Sutanto, Perjanjian Baru Interlinier Yunani-Indonesia dan Konkordansi Perjanjian Baru (PBIK) (Jakarta: Lembaga Alkitab Indonesia, 2019), II:661.

${ }^{27}$ H.G. Liddell, A Lexicon: Abridged from Liddell and Scott's Greek-English Lexicon (Oak Harbor, WA: Logos Research Systems, Inc, 1996), 661. 
bisa bermakna kematian orang. ${ }^{28}$ Thayer mengartikan kata ini sebagai "to lead over, carry over, transfer; to lead one's self across; to take one's way, betake one's self, set out, depart; ${ }^{29}$ Menurut Lexham, kata

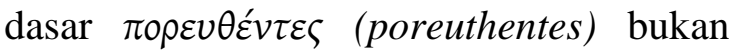

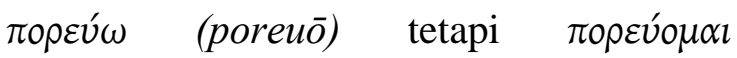
(poreuomai). Kata ini berarti "to follow, to go after; to go, to go out; to proceed, to travel; to be on the way, to be journeying." 30 Friberg dkk. mengartikan sebagai berikut: (1) secara harfiah: (a) pergi dari satu tempat ke tempat lain pergi, wisata; (b) dengan indikasi titik asal berangkat (dari); (c) dengan indikasi tujuan pergi (untuk), melanjutkan (ke arah); (2) kiasan: (a) mati, meninggalkan kehidupan ini; (b) berperilaku; (c) perintah yang mencakup pergi untuk bermisi." 31 Arndt dkk. mengartikan "(1) to move over an area with a point of departure or destination specified, go, proceed, travel; (2) to conduct oneself, live, walk; (3) go to one's death." 32

\footnotetext{
${ }^{28}$ Arndt et al., A Greek-English Lexicon of the New Testament and Other Early Christian Literature: A Translation and Adaption of the Fourth Revised and Augmented Edition of Walter Bauer's GriechischDeutsches Worterbuch Zu Den Schrift En Des Neuen Testaments Und Der Ubr, 692.

${ }^{29}$ Joseph Henry Thayer, A Greek-English Lexicon of the New Testament: Being Grimm's Wilke's Clavis Novi Testamenti, Originally Published (New York: Harper \& Brother, 1889), 531.

${ }^{30}$ The Lexham Analytical Lexicon to the Greek New Testament (Logos Research Systems, Inc, 2008).

${ }^{31}$ Friberg, Friberg, dan Miller, Analytical Lexicon of the Greek New Testament, Baker's Greek New Testament library, 4:323.
}

Moulton memberi arti untuk kata

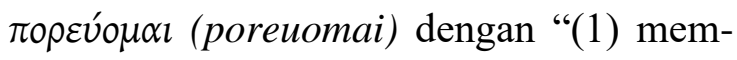
bawa, pergi dari satu tempat ke tempat yang lain; pergi, enyah; meninggal; pergi, berangkat, kepergian; mengikuti, menuruti; kenikmatan hidup, hidup, berada dalam keadaan apapun; (2) hal pergi, perjalanan; cara hidup; dagangan, pengusahaan". ${ }^{33}$ Kittel memberikan pengertian untuk kata ini dengan "to set in motion," "to convey," "to lead," "to bring," "to send"; "to go," "to travel," "to journey". Penggunaan imperatif mengekspresikan kedaulatan Allah dalam memerintah Yusuf (Mat. 2:20); Yesus dalam kuasa penyembuhan berkata kepada orang sakit untuk pergi ke rumah (Luk. 5:24); Yesus mengutus murid-murid-Nya untuk pergi bermisi (Mat. 10:6-7). ${ }^{34}$

Dengan beberapa arti yang dikemukakan tersebut, maka peneliti memberikan

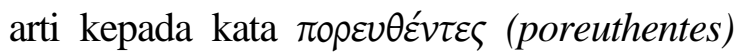
yang merupakan kata kerja partisipel dengan arti imperatif, yaitu "pergi dari satu tempat ke tempat tujuan lain dengan mak-

\footnotetext{
${ }^{32}$ Arndt et al., A Greek-English Lexicon of the New Testament and Other Early Christian Literature: A Translation and Adaption of the Fourth Revised and Augmented Edition of Walter Bauer's GriechischDeutsches Worterbuch Zu Den Schrift En Des Neuen Testaments Und Der Ubr.

33 Harold K. Moulton, Leksikon Analitis Bahasa Yunani yang Direvisi, 312.

34 Gerhard Kittel, Friedrich, dan Bromiley, Theological Dictionary of the New Testament, Translation of: Theologisches Worterbuch Zum Neuen Testament, 915.
} 
sud menjalankan misi." Seperti halnya perintah untuk pergi dalam maksud menjalankan misi di lingkungan orang-orang Israel (Mat. 10:6-7), maka pergi yang dimaksud dalam Matius 28:19 ini juga dalam maksud menjalankan misi, tetapi bukan hanya di lingkungan orang-orang Israel melainkan ke wilayah yang lebih luas. Dalam konteks masa kini, pergi dapat diartikan upaya pemberitaan Injil ke luar (ke luar dari keluarga, lingkungan, kelompok masyarakat, bahkan bangsa).

\section{Aspek Kedua Amanat Agung: Baptislah

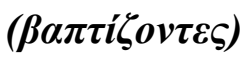

Kata $\beta \alpha \pi \tau i ́$ (ov $\tau \varepsilon \zeta$ (baptizontes) adalah kata kerja partisipel presen aktif nominatif maskulin orang kedua jamak. Kata ini berasal dari kata dasar $\beta \alpha \pi \tau i \zeta{ }^{\prime} \omega$ (baptizō). Hasan Sutanto mengartikan kata ini sebagai "membasuh (dalam penyucian ritual orang Yahudi); membaptis." ${ }^{35}$ Di bawah kata $\beta \alpha \pi \tau \omega$ (baptō), Moulton menempatkan kata $\beta \alpha \pi \tau i \zeta \omega$ (baptizō) dan mengartikannya dengan "membaptis, mencuci, membaptiskan; memberi diri dibaptis, dibaptiskan."36 Liddell mengartikan kata $\beta \alpha \pi \tau i \zeta \zeta \omega$ (baptizō) dengan "to dip in or under water; to get

35 Sutanto, Perjanjian Baru Interlinier YunaniIndonesia dan Konkordansi Perjanjian Baru (PBIK).

${ }^{36}$ Harold K. Moulton, Leksikon Analitis Bahasa Yunani yang Direvisi.

${ }^{37}$ H.G. Liddell, A Lexicon : Abridged from Liddell and Scott's Greek-English Lexicon.

${ }^{38}$ Arndt et al., A Greek-English Lexicon of the New

Testament and Other Early Christian Literature : A oneself baptized." 37 Arndt dan Gingrich mengartikan dengan "dip, immerse, dip oneself, wash." Selanjutnya juga ditambahkan penjelasan: (1) ritual pembasuhan Yahudi; (2) arti khusus baptis (a) dilakukan orang Yohanes Pembaptis; (b) baptisan Kristen; (3) arti figuratif yang dihubungkan dengan baptisan Kristen (a) tipologi Israel yang menyeberangi Laut Merah; (b) baptisan api; (c) kemartiran. ${ }^{38}$ Thayer memberikan arti “(1) dalam arti umum to dip repeatedly, to immerge, submerge; (2) to cleanse by dipping or submerging, to wash, to make clean with water; dalam arti metafora (3) to overwhelm; to be overwhelmed with calamities." 39 Friberg memberikan penjelasan, bahwa dalam PB terutama adalah tentang penggunaan air dalam arti religius dan simbolik: (1) ritual pembasuhan Yahudi, membasuh, membersihkan, memurnikan dengan mencuci; (2) sebagai ritus simbolik yang menunjukkan hubungan dengan Kristus; (3) sebagai kiasan yang mengacu kepada ide-ide yang berhubungan dengan baptisan, dari tindakan komitmen dan identifikasi, dari hal menerima

Translation and Adaption of the Fourth Revised and Augmented Edition of Walter Bauer's GriechischDeutsches Worterbuch Zu Den Schrift En Des Neuen Testaments Und Der Ubr.

39 Thayer, A Greek-English Lexicon of the New Testament: Being Grimm's Wilke's Clavis Novi Testamenti, Originally Published. 
Roh Kudus, dari hal pencobaan dan kemar$\operatorname{tiran}^{40}$

Baptisan adalah upacara yang menandai seorang menjadi bagian dari jemaat Allah. Implikasi dari perintah membaptiskan adalah menjadikan orang yang sudah mendengar Injil akhirnya percaya kepada Yesus dan menjadi bagian dari umat Allah.

\section{Aspek Ketiga Amanat Agung: Ajarlah ( $\delta ı \delta \alpha ́ \sigma \kappa o v \tau \varepsilon \varsigma)$}

Kata $\delta i \delta \alpha ́ \sigma \kappa o v \tau \varepsilon \varsigma$ (didaskontes) adalah kata kerja partisipel presen aktif nominatif maskulin orang kedua jamak. Kata ini berasal dari kata dasar $\delta i \delta \alpha ́ \sigma \kappa \omega$ (didaskō). Hasan Sutanto mengartikan kata ini sebagai "mengajar; mengajarkan."41 Moulton mengartikan dengan "mengajar(kan); mengajar atau berbicara di muka perkumpulan umum; memerintah; memperingatkan." $" 42$

Tuhan Yesus memerintahkan kepada murid-murid-Nya untuk memberitakan Injil bukan hanya supaya orang menjadi percaya saja, menjadi pengikut saja, tetapi ada satu tujuan yang pasti dari Tuhan Yesus yaitu supaya setiap orang diajar untuk melakukan semua yang telah diperintahkanNya. Terlihat dalam perintah mengajar ini

\footnotetext{
${ }^{40}$ Friberg, Friberg, dan Miller, Analytical Lexicon of the Greek New Testament, Baker's Greek New Testament library, vol. 4.

41 Sutanto, Perjanjian Baru Interlinier YunaniIndonesia dan Konkordansi Perjanjian Baru (PBIK).
}

tidak hanya sampai pada aspek kognitif dan afektif tetapi sampai pada aspek psikomotorik. Perintah mengajar ini bukan hanya sampai murid mengerti atau memperbaharui sikap, gol dari mengajar adalah sampai murid melakukan semua yang sudah Tuhan Yesus perintahkan.

\section{Mengenal Era Masyarakat 5.0}

Perubahan sosial bersamaan dengan perkembangan teknologi adalah hal yang merupakan keniscayaan; dari satu era ke era berikutnya, selalu terjadi perubahan seiring dengan perkembangan teknologi yang begitu pesat dan masif. Negara yang pertama kali meluncurkan gagasan Society 5.0 adalah negara Jepang, dengan tujuan untuk menjawab tantangan perkembangan teknologi dan problem humanistis. Perdana Menteri Jepang Shinzo Abe dalam pertemuan Forum Ekonomi Dunia (World Economic Forum/WEF) di Davos Swiss tanggal 23 Januari 2019 menyatakan bahwa Negara Jepang mempunyai visi mengenai Masyarakat 5.0 atau Society 5.0. ${ }^{43}$ Masyarakat era 5.0 adalah sebuah konsep yang dibangun dengan berpusat pada manusia (human centered) dan berbasis teknologi. Peran manusia diarahkan kepada optimalisasi per-

\footnotetext{
42 Harold K. Moulton, Leksikon Analitis Bahasa Yunani yang Direvisi.

${ }^{43}$ Decky Hendarsyah, "E-commerce di era industri 4.0 dan society 5.0," IQTISHADUNA: Jurnal Ilmiah Ekonomi Kita 8, no. 2 (2019): 171-184.
} 
kembangan teknologi guna menciptakan ruang kemanusiaan yang lebih bermakna. ${ }^{44}$

Dari sejarah perkembangan tersebut jelas bahwa generasi milenial sekarang ini merupakan generasi yang oleh Fukuyama seperti dikutip oleh Rojko disebut sebagai generasi era industrialisasi 4.0 yang ditandai dengan IoT, artificial intelligence, robotics, big data dan blockchain. ${ }^{45}$ Era masyarakat 5.0 memiliki ciri yang tidak jauh berbeda dengan era industrialisasi 4.0. Pada era masyarakat 5.0 manusia diharapkan memanfaatkan sebesar-besarnya perkembangan teknologi demi mencapai kesejahteraan yang utuh dari manusia itu sendiri. ${ }^{46}$ Dimas dan Lenawati menyatakan bahwa Society 5.0 adalah representasi bentuk sejarah perkembangan masyarakat ke5. ${ }^{47}$ Untuk mengerti perbedaan masyarakat manusia di setiap era, Hendarsyah membuat tabel perbandingan dengan mengolah dari berbagai sumber.
Tabel Komparasi Waktu, Tahapan
Masyarakat dan Revolusi Industri ${ }^{48}$

\begin{tabular}{clll}
\hline No. & Waktu & $\begin{array}{c}\text { Tahapan } \\
\text { Masyarakat }\end{array}$ & $\begin{array}{c}\text { Revolusi } \\
\text { Industri }\end{array}$ \\
\hline 1 Awal & Society 1.0 & - \\
manusia & Berburu & \\
ada & & \\
2 13.000 & Society 2.0 & - \\
Sebelum & Bercocok & \\
Masehi & tanam & \\
3 Abad & Society 3.0 & Industri \\
XVIII & Industri & 1.0 \\
& & & Tahun \\
& & & $1800-$ an \\
4 Abad & Society 3.0 & Industri \\
XIX & Industri & 2.0 \\
& & Tahun \\
& & $1900-$ an \\
5 Abad & Society 4.0 & Industri \\
XX & Informatif & 3.0 \\
& dan keratif & Tahun \\
& & $1960-$ an \\
Abad & Society 5.0 & Industri \\
XXI & Super & 4.0 \\
& cerdas & Tahun \\
& & 2011 \\
\hline
\end{tabular}

Dari tabel komparasi waktu, tahapan masyarakat dan revolusi industri tersebut tampak jelas bahwa era industrialisasi 4.0 dengan era masyarakat 5.0 memiliki kesamaan namun juga memiliki perbedaan pada beberapa bagian implementasi. Persamaan era Industrialisasi 4.0 dan Society 5.0 adalah sama-sama sebuah konsep pengemba-

\footnotetext{
47 Dimas Setiawan dan Mei Lenawati, "Peran dan Strategi Perguruan Tinggi dalam Menghadapi Era Society 5.0," RESEARCH : Computer, Information System \& Technology Management 3, no. 1 (2020): 1 .

${ }^{48}$ Hendarsyah, "E-commerce di era industri 4.0 dan society 5.0."
}

44 Dhiana Kusumawati et al., Implementasi Teknologi Untuk Pemberdayaan Masyarakat Menuju Era Society 5.0, ed. Arief Nuryana, Kristina Andryani, dan M. Nastain, Cetakan Ke. (Jogjakarta: MBridge Press, 2019).

45 Andreja, "Industry 4.0 Concept: Background and Overview."

${ }^{46}$ Hendarsyah, "E-commerce di era industri 4.0 dan society 5.0." 
ngan teknologi yang berbasis pada Internet of Things, Big data, dan Artifical Intelligence, dengan demikian pada kedua era tersebut sama-sama menekankan optimalisasi pemanfaatan perkembangan teknologi. Sedangkan perbedaannya terletak pada tujuan atau orientasi dari optimalisasi penggunaan perkembangan teknologi tersebut. Dimas dan Lenawati menulis bahwa dalam perspektif historis Society 5.0 adalah sebuah konsep yang dicetuskan oleh Keidanren, sebuah federasi bisnis di jepang, yang berbasis pada Internet of Things, Big data, dan Artifical Intelligence yang tujuan utamanya diperuntukkan bagi kehidupan manusia yang lebih baik. Sementara Revolusi industri 4.0 adalah sebuah konsep pengembangan teknologi yang tujuan utamanya berorientasi pada produktifitas proses bisnis ${ }^{49}$.

Aspek perbedaan tampak jelas dari tujuan dan orientasi utama penggunaan Internet of Things, Big data, dan Artifical Intelligence tersebut, bahwa dalam industrialisasi 4.0 hal tersebut semata-mata hanya ditujukan untuk peningkatan produktivitas proses bisnis sementara dalam era masyarakat 5.0 tujuan utamanya adalah kehidupan manusia yang lebih baik. Penekanan tujuan optimalisasi pemanfaatan teknologi di era

\footnotetext{
49 Setiawan dan Lenawati, "Peran dan Strategi Perguruan Tinggi dalam Menghadapi Era Society 5.0."

50 T. K. Lestari dan A. Y. Supriadi, Statistik Telekomunikasi Indonesia 2019, ed. E. Sari, S.
}

masyarakat 5.0 menjadikan manusia bukan saja sebagai objek melainkan menjadi subjek yang layak untuk menikmati manfaat dari berkembangnya teknologi yang amat sangat pesat ini.

\section{Aktualisasi Amanat Agung Di Era Masyarakat 5.0}

Membaca Peluang dan Tantangan Aktualisasi Amanat Agung di Era Masyarakat 5.0

Badan Pusat Statistik Indonesia merilis statistik telekomunikasi Indonesia pada tahun 2019 berdasarkan pendataan Survei Sosial Ekonomi Nasional (Susenas) 2019, populasi penduduk Indonesia yang telah mengakses internet di tahun 2019 sebanyak 47,69 persen. ${ }^{50}$ Sementara menurut Kompas.com pada awal tahun 2021 pengguna internet di Indonesia menembus angka 202,6 juta penduduk dari populasi penduduk 274,9 juta jiwa atau mencapai penetrasi 73,4 persen yang didominasi oleh penduduk berusia 16-64 tahun. ${ }^{51}$ Tingginya angka penggunaan internet di Indonesia menunjukkan adanya keterbukaan informasi dan penerimaan masyarakat terhadap perkembangan teknologi dan informasi. Salah satu penyebab naiknya penggunaan internet oleh

Utoyo, dan L. Anggraini (Jakarta: Badan Pusat Statistik, 2019).

${ }^{51}$ Galuh Putri Riyanto, "Jumlah Pengguna Internet Indonesia 2021 Tembus 202 Juta,” Kompas.com. 
masyarakat Indonesia, menurut data BPS adalah disebabkan oleh naiknya pengguna telepon selular ketimbang telepon kabel. Data penduduk Indonesia yang telah menggunakan telepon selular di tahun 2019 telah mencapai angka sebanyak 89,09 persen. $^{52}$ Sedangkan rumah tangga Indonesia baik yang di perkotaan maupun di pedesaan yang telah memiliki serta menggunakan komputer sebanyak 18,78 persen yang sebaran penggunanya terdapat di pulau Sumatera, Jawa, Kalimantan, Sulawesi, Bali dan Nusa Tenggara, serta Maluku dan Papua. ${ }^{53}$ Sementara Kompas.com menulis bahwa penduduk Indonesia berusia 16-64 tahun pada awal tahun telah menggunakan telepon genggam, laptop/PC, tablet, smartwatch, dan sebagainya dimana dari berbagai alat komunikasi tersebut telepon genggam memiliki peringkat pengguna teratas mencapai 98,3 persen. ${ }^{54}$

Fakta di atas merupakan tantangan sekaligus peluang yang dihadapi oleh gereja dalam aktualisasi amanat agung di era masyarakat 5.0. Sebagai sebuah tantangan, karena di era masyarakat 5.0 ini gereja diperhadapkan dengan adanya keharusan untuk merancang inovasi baru dari misi berbasis on site menuju Digital Mission, yang mengharuskan misionaris memiliki serta

52 Lestari dan Supriadi, Statistik Telekomunikasi Indonesia 2019.

53 Ibid. menguasai akses internet yang memadai serta memiliki kemampuan untuk merancang inovasi dan kreativitas misi gereja dengan memanfaatkan IoT (Internet of Things) dan layanan virtual. Di sini gereja dituntut bukan saja memiliki ketersediaan akses internet, namun juga untuk memiliki sumber daya manusia (SDM) yang mumpuni untuk merancang program misi digital serta mempergunakan media sosial berbasis teknologi digital sebagai sarana pelaksanaan amanat agung Kristus. Berkenaan dengan hal ini beberapa gereja sudah melakukan hal tersebut, bukan hanya menggunakan internet dan alat-alat komunikasi berbasis daring, tetapi juga telah memiliki sumber daya yang bisa mengoperasikannya, sebagai contoh GKII, GBI, GRII, GBIKA Surakarta, GBIS Kepunton Surakarta telah melaksanakan kegiatan ibadah dengan menggunakan media sosial, seperti Facebook dan Youtube. Melihat hal ini dapat disimpulkan bahwa sebenarnya gereja telah mengikuti tren yang ada pada era Revolusi Industri 4.0 maupun era Society 5.0.

Selain merupakan tantangan, juga merupakan peluang atau kesempatan emas bagi pelaksanaan amanat agung Kristus. Sebagai sebuah peluang bagi gereja, khususnya gereja-gereja di Indonesia, karena de-

54 Riyanto, "Jumlah Pengguna Internet Indonesia 2021 Tembus 202 Juta." 
ngan adanya kesiapan masyarakat Indonesia untuk menggunakan layanan teknologi digital membuka peluang diterimanya berita Injil lebih tinggi. Senada dengan itu, Indonesia kini memasuki era bonus demografi, ${ }^{55}$ penduduk Indonesia yang didominasi oleh usia produktif (16-64 tahun) membuka peluang bagi pemimpin Kristen untuk melaksanakan misi dan pengembangan gereja. $^{56}$

\section{Kontekstualisasi Amanat Agung di Era Society 5.0}

Data-data tersebut di atas merupakan petunjuk bagi gereja dalam mengimplementasikan amanat agung di era Society 5.0 ini. Bagaimana mandat menjadikan murid yang diikuti dengan langkah-langkah yang menyertainya, yaitu "pergi," "membaptis," dan "mengajar" di aktualisasikan secara kontekstual di era ini. Beberapa hal yang kontekstual dan relevan untuk dilakukan oleh gereja di antaranya adalah dengan mengubah metode berbasis on site atau off line menuju misi on line. Misi on line atau misi digital dapat dilakukan de-

\footnotetext{
55 Rahmat Kristiono, "Bonus Demografi Sebagai Peluang Pelayanan Misi Gereja di Kalangan MudaMudi," Jurnal Teologi Berita Hidup 1, no. 2 (Maret 31, 2019): 174-182, https://lpmplampung. kemdikbud.go.id/detailpost/mengenal-modelpembelajaran-discovery-learning.

${ }^{56}$ David Eko Setiawan, "Kepemimpinan Kristen di Era Bonus Demografi Pasca Sensus Penduduk Indonesia Tahun 2020," KInaa: Jurnal Kepemimpinan Kristen dan Pemberdayaan Jemaat 2, no. 1 (2021): 12-27.
}

ngan memanfaatkan media sosial yang telah familier dan dimiliki oleh mayoritas penduduk Indonesia seperti peneliti paparkan di atas. $^{57}$

Sebelum era masyarakat 5.0 "pergi" dapat diartikan beranjak melintasi batas teritorial. Berbaurnya dunia nyata dengan dunia digital, pada masyarakat 5.0 memberikan makna baru bagi pergi, yaitu beranjak dari pemberitaan Injil di dunia nyata kepada pemberitaan Injil di dunia maya. Kontekstualisasi Amanat Agung pada era misi tradisional berupaya membawa Injil ke dalam konteks budaya masyarakat penerima Injil, ketika misi ditujukan kepada masyarakat urban maka diperlukan pula upaya kontekstualisasi ke dalam budaya urban. ${ }^{58}$ Demikian pula pada era Society 5.0 diperlukan upaya untuk membawa Injil ke dalam konteks budaya digital. Memasuki masyarakat dengan budaya digital diperlukan kesiapan pembawa berita Injil memahami budaya digital tersebut berikut masyarakat yang telah hidup di dalamnya.

Selain itu "pergi" yang biasanya dilakukan dengan beranjak untuk bertemu

\footnotetext{
57 Yovianus Epan dan Paulus Purwoto, "Metode Pemberitaan Kabar Baik Tuhan Yesus Dalam Matius 4:23-25 Dan Aplikasinya Bagi Pemberitaan Kabar Baik Di Era Revolusi Industri 4.0," Miktab: Jurnal Teologi dan Pelayanan Kristiani 1, no. 1 (2021): 1-27, https://stttorsina.ac.id/jurnal/index. $\mathrm{php} / \mathrm{miktab} / \mathrm{article} / \mathrm{view} / 278$.

58 Joseph Christ Santo, "Misi Kota: Bentuk Pelayanan di Wilayah Urban," Jurnal Teologi ElShadday 3, no. 1 (2016): 41-55.
} 
langsung dengan target misi, pada era Society 5.0 sangat dimungkinkan untuk dilakukan secara daring dengan menggunakan media sosial seperti Facebook, WhatsApp, Youtube, dan sebagainya. Senada dengan hal tersebut, Arifianto, Saptorini dan Kalis menulis bahwa media sosial memiliki hal penting dalam melaksanakan misi gereja. ${ }^{59}$ Bahkan aktualisasi "pergi" dalam era masyarakat 5.0 juga bisa dilakukan dengan berjejaring secara daring dengan pelaku-pelaku misi di berbagai tempat.

Perintah untuk membaptis secara harfiah mengharuskan adanya kontak antara yang membaptis dengan yang dibaptis. Hamba Tuhan yang membaptis harus memberikan tindakan pada orang yang dibaptis dengan menggunakan air sebagai media baptisan. Itu sebabnya diperlukan gagasan dengan dasar teologi yang benar untuk melakukan baptisan secara daring. Tulisan ini memberi sebuah masukan untuk melaksanakan sakramen baptisan dengan cara daring. Pelaksanaan baptisan daring memerlukan aplikasi realtime yang mendukung tindakan bersama di tempat yang berbeda, misalnya dengan aplikasi panggilan video. Pada tempat yang satu hadir hamba Tuhan yang berwewenang untuk menyelenggara-

\footnotetext{
${ }^{59}$ Yonatan Alex Arifianto, Sari Saptorini, dan Kalis Stevanus, "Pentingnya Peran Media Sosial dalam Pelaksanaan Misi di Masa Pandemi Covid-19.," HARVESTER: Jurnal Teologi dan Kepemimpinan Kristen 5, no. 2 (2020): 86-104.
}

kan baptisan, dan pada tempat yang lain hadir orang yang dibaptis dan saksi untuk mengonfirmasi. Sementara penerima baptisan mengikuti arahan dari pendeta melalui panggilan video, ada saksi yang mendampingi dan mengonfirmasi bahwa penerima baptisan sudah menyelamkan diri di dalam air. Karena hamba Tuhan yang membaptis berada di tempat yang berbeda, maka posisi baptisan selam adalah membenamkan diri sendiri ke dalam air bukan dibaringkan ke dalam air.

Perintah yang ketiga adalah mengajar. Yesus mengajar dengan berbagai pendekatan, kadang-kadang Ia mengajar dengan perumpamaan, kadang-kadang dengan kalimat lugas. Ia mengajar di berbagai tempat, kadang-kadang di sinagoge, di bukit, dan dalam rumah. Model pengajaran ini sejalan yang diajarkan Musa dalam Ulangan 6:6-7 bahwa mengajar dapat dilakukan dalam berbagai situasi. Beralihnya budaya kepada masyarakat 5.0 membawa wacana baru bentuk pengajaran, yaitu melalui pengajaran daring, dan hal ini tidak bertentangan dengan semangat yang didengungkan dalam Ulangan 6:6-7. ${ }^{60}$ Ada bentuk-bentuk pengajaran secara daring. Dunia pendidikan secara terpaksa sudah melaku-

60 Sonny Eli Zaluchu, Era Baru Pembelajaran Daring di Perguruan Tinggi Teologi: Orasi Ilmiah (Karanganyar: Sekolah Tinggi Teologi Berita Hidup, 2021). 
kan pengajaran secara daring ketika pandemi Covid-19 merebak, yang justru mempercepat berbagai inovasi pendidikan secara daring. Aspek pengajaran dari Amanat Agung dapat memanfaatkan bentuk-bentuk yang sudah berkembang tersebut.

\section{KESIMPULAN}

Amanat Agung adalah menjadikan semua bangsa murid dengan langkah pergi, membaptis, dan mengajar. Aktualisasi Amanat Agung Kristus pada era Society 5.0 menuntut inovasi baru dari misi berbasis on site menuju Digital Mission, yang mengharuskan gereja dan misionaris memiliki serta menguasai akses internet yang memadai serta memiliki kemampuan untuk merancang inovasi dan kreativitas misi gereja dengan memanfaatkan IoT (Internet of Things) dan layanan virtual, baik itu pada aspek pergi, baptis, dan ajar.

\section{UCAPAN TERIMA KASIH}

Diucapkan terima kasih juga kepada penulis kedua, Asih Rachmani Endang Sumiwi, yang memberikan kontribusi dalam analisis teks Yunani; kepada penulis ketiga, Alfons Renaldo Tampenawas, yang memberikan kontribusi dalam penambahan referensi; dan kepada penulis ketiga, Joseph Christ Santo, yang menyempurnakan tulisan ini.

\section{DAFTAR PUSTAKA}

Andreja, Rojko. "Industry 4.0 Concept: Background and Overview." International Journal of Interactive Mobile Technologies (iJIM) 5 No 11 (2017).

Arifianto, Yonatan Alex, Sari Saptorini, dan Kalis Stevanus. "Pentingnya Peran Media Sosial dalam Pelaksanaan Misi di Masa Pandemi Covid-19." HARVESTER: Jurnal Teologi dan Kepemimpinan Kristen 5, no. 2 (2020): 86-104.

Arndt, William, F. Wilbur Gingrich, Frederick W. Danker, dan Walter Bauer. A Greek-English Lexicon of the New Testament and Other Early Christian Literature: A Translation and Adaption of the Fourth Revised and Augmented Edition of Walter Bauer's Griechisch-Deutsches Worterbuch $\mathrm{Zu}$ Den Schrift En Des Neuen Testaments Und Der Ubr. Chicago: University of Chicago Press, n.d.

Bosh, David J. Transformasi Misi Kristen Sejarah Teologi Misi yang Mengubah dan Berubah. Diedit oleh Staf Redaksi BPK Gunung Mulia. Jakarta: BPK Gunung Mulia, 2018.

Darmawan, I Putu Ayub. "Jadikanlah Murid: Tugas Pemuridan Gereja Menurut Matius 28:18-20." Evangelikal: Jurnal Teologi Injili dan Pembinaan Warga Jemaat (2019).

Epan, Yovianus, dan Paulus Purwoto. "Metode Pemberitaan Kabar Baik Tuhan Yesus Dalam Matius 4:23-25 Dan Aplikasinya Bagi Pemberitaan Kabar Baik Di Era Revolusi Industri 4.0." Miktab: Jurnal Teologi dan Pelayanan Kristiani 1, no. 1 (2021): 1$27 . \quad$ https://stttorsina.ac.id/jurnal/ index.php/miktab/article/view/278. 
Friberg, Timothy, Barbara Friberg, dan Neva F. Miller. Analytical Lexicon of the Greek New Testament, Baker's Greek New Testament library. Vol. 4. Grand Rapids, Mich.: Baker Books, 2000 .

Gerhard Kittel, Gerhard Friedrich, dan Geoffrey William Bromiley. Theological Dictionary of the New Testament, Translation of: Theologisches Worterbuch Zum Neuen Testament. Grand Rapids, Mich.: W.B. Eerdmans, n.d.

GP, Harianto. Teologi Misi dari Misio Dei Menuju Misio Ecclesia. Yogyakarta: Penerbit ANDI, 2017.

H.G. Liddell. A Lexicon: Abridged from Liddell and Scott's Greek-English Lexicon. Oak Harbor, WA: Logos Research Systems, Inc, 1996.

Harold K. Moulton. Leksikon Analitis Bahasa Yunani yang Direvisi. Jogjakarta: Randa Family Press, 2018.

Hartono, Handreas. "Mengaktualisasikan Amanat Agung Matius 28: 19-20 dalam Konteks Era Digital.” KURIOS (Jurnal Teologi dan Pendidikan Agama Kristen) 4, no. 2 (2018): 1920.

Hendarsyah, Decky. "E-commerce di era industri 4.0 dan society 5.0." IQTISHADUNA: Jurnal Ilmiah Ekonomi Kita 8, no. 2 (2019): 171184.

Kristiono, Rahmat. "Bonus Demografi Sebagai Peluang Pelayanan Misi Gereja di Kalangan Muda-Mudi." Jurnal Teologi Berita Hidup 1, no. 2 (Maret 31, 2019): 174-182. https://lpmplampung.kemdikbud.go.id /detailpost/mengenal-modelpembelajaran-discovery-learning.

Kusumawati, Dhiana, Siti Tamaroh, Muhamad Riyanto, Bayu Kanetro, Suryo Widianto, Dwiyati Pujimulyani, Barinta Widaryanti, et al.
Implementasi Teknologi Untuk Pemberdayaan Masyarakat Menuju Era Society 5.0. Diedit oleh Arief Nuryana, Kristina Andryani, dan M. Nastain. Cetakan Ke. Jogjakarta: MBridge Press, 2019.

Lestari, T. K., dan A. Y. Supriadi. Statistik Telekomunikasi Indonesia 2019. Diedit oleh E. Sari, S. Utoyo, dan L. Anggraini. Jakarta: Badan Pusat Statistik, 2019.

Moleong, Lexy J. Metodologi Penelitian Kualitatif. Cet. Ke-36. Bandung: PT Remaja Rosdakarya, 2017.

Munthe, Eben. "Mengoptimalkan Karunia dalam Jemaat untuk Melakukan Misi Amanat Agung di Era 4.0." EPIGRAPHE: Jurnal Teologi dan Pelayanan Kristiani 3, no. 2 (2019): 133.

Nastiti, Faulinda Ely, dan Aghni Rizqi Ni'mal 'Abdu. 'Kesiapan Pendidikan Indonesia Menghadapi era society 5.0." Edcomtech 5, no. 1 (2020): 6166.

Pasaribu, Marulak. Eksposisi Injil Sinoptik Mengenal Yesus yang Diberitakan dalam Injil Matius, Markus dan Lukas. Diedit oleh Tjuk Subandiah Kaihatu. Malang: Gandum Mas, 2019.

Peters, George W. Teologi Alkitabiah tentang Pekabaran Injil. Malang: Penerbit Gandum Mas Malang, 2020.

Purwoto, Paulus. "Makna Proselitisasi Di Masa Intertestamental Bagi Misi." EPIGRAPHE: Jurnal Teologi dan Pelayanan Kristiani 4, no. 2 (2020). Gereja Sejati dan Aplikasinya Bagi Pelayanan Gereja Kontemporer." Shamayim: Jurnal Teologi dan Pendidikan Kristiani 1, no. 1 (2020): 45-57.

Purwoto, Paulus, dan Asih Rachmani Endang Sumiwi. "Pola Manajemen 
Penginjilan Paulus Menurut Kitab

Kisah Para Rasul 9-28." Angelion: Jurnal Teologi dan Pendidikan Kristen Vol 1, No, no. 2 (2020): 113-131.

Riyanto, Galuh Putri. “Jumlah Pengguna Internet Indonesia 2021 Tembus 202 Juta.” Kompas.com.

Santo, Joseph Christ. "Konsep Menjadikan Murid Berdasarkan Matius 28:19-20." Jurnal Teologi El-Shadday 3, no. 2 (2016): 7-33.

_ . "Misi Kota: Bentuk Pelayanan di Wilayah Urban." Jurnal Teologi ElShadday 3, no. 1 (2016): 41-55.

Setiawan, David Eko. "Kepemimpinan Kristen di Era Bonus Demografi Pasca Sensus Penduduk Indonesia Tahun 2020.” KINAA: Jurnal Kepemimpinan Kristen dan Pemberdayaan Jemaat 2, no. 1 (2021): 12-27.

Setiawan, Dimas, dan Mei Lenawati. "Peran dan Strategi Perguruan Tinggi dalam Menghadapi Era Society 5.0." RESEARCH : Computer, Information System \& Technology Management 3, no. 1 (2020): 1.

Sproul, R.C. Kebenaran-kebenaran Dasar Iman Kristen. Malang: Departemen Literatur SAAT, 2002.
Susanto, Hasan. Perjanjian Baru Interlinear Yunani-Indonesia dan Konkordansi Perjanjian Baru (PBIK) Jilid I-II. Malang: Lembaga Alkitab Indonesia, 2014.

Susanto, Hery. "Gereja Yang Berfokus Pada Gerakan Misioner." FIDEI: Jurnal Teologi Sistematika dan Praktika 2, no. 1 (2019): 62-80.

Sutanto, Hasan. Perjanjian Baru Interlinier Yunani-Indonesia dan Konkordansi Perjanjian Baru (PBIK). Jakarta: Lembaga Alkitab Indonesia, 2019.

Thayer, Joseph Henry. A Greek-English Lexicon of the New Testament: Being Grimm's Wilke's Clavis Novi Testamenti, Originally Published. New York: Harper \& Brother, 1889.

Zaluchu, Sonny Eli. Era Baru Pembelajaran Daring di Perguruan Tinggi Teologi: Orasi Ilmiah. Karanganyar: Sekolah Tinggi Teologi Berita Hidup, 2021.

The Lexham Analytical Lexicon to the Greek New Testament. Logos Research Systems, Inc, 2008. 